\title{
Synthesis, Crystal Structure and Catalytic Activity of Dioxidomolybdenum(VI) Complex with Tridentate ONO Aroylhydrazone Ligand
}

\author{
Min Liang ${ }^{1, *}$ and Dong-Hui Zou ${ }^{2}$ \\ ${ }^{1}$ School of Chemistry and Chemical Engineering, Qiqihar University, Qiqihar 161006, P. R. China. \\ ${ }^{2}$ College of Food and Bio-Engineering, Qiqihar University, Qiqihar 161006, P. R. China. \\ * Corresponding author: E-mail: liangmin09@ 163.com
}

Received: 09-12-2015

\begin{abstract}
A novel dioxidomolybdenum complex, $\left[\mathrm{MoO}_{2} \mathrm{~L}\right]$, derived from the tridentate aroylhydrazone 2-amino- $N$ '-(2-hydroxy3-methylbenzylidene)benzohydrazide $\left(\mathrm{H}_{2} \mathrm{~L}\right)$, has been prepared and characterized by elemental analysis, FT-IR, ${ }^{1} \mathrm{H}$ NMR, and single crystal structural X-ray diffraction. The complex has distorted square pyramidal structure in which the aroylhydrazone ligand behaves as a binegative donor, leaving the amino-N group uncoordinated towards the metal center. Single crystal structure analysis reveals that the Mo(VI) center is coordinated by the donor atoms of the binegative aroylhydrazone ligand and two oxido groups. Crystal structure of the complex is stabilized by hydrogen bonds. The complex functions as an effective olefin epoxidation catalyst with hydrogen peroxide as terminal oxidant and sodium hydrogen carbonate as a co-catalyst.
\end{abstract}

Keywords: Aroylhydrazone; Dioxidomolybdenum complex; Catalytic activity; Crystal structure

\section{Introduction}

In the last few years, considerable attention has focused on the coordination chemistry of molybdenum because of its biochemical significance ${ }^{1}$ as well as involvement of Mo(VI) compounds in some industrial catalytic processes. ${ }^{2}$ Molybdenum complexes are widely used as efficient catalysts in different processes such as the oxidation of olefins and sulfides. ${ }^{3}$ Aroylhydrazones are potential tridentate ligands. ${ }^{4}$ During search of literature, we found that most molybdenum complexes with aroylhydrazones have octahedral coordination. ${ }^{5}$ The only example of square pyramidal coordination of molybdenum complexes with aroylhydrazone ligand was reported by Ghosh and coworkers. ${ }^{6}$ In the present work, a novel molybde-<smiles>Cc1cccc(/C=N/NC(=O)c2ccccc2N)c1O</smiles>

Scheme 1. $\mathrm{H}_{2} \mathrm{~L}$
num(VI) complex with square pyramidal coordination, $\left[\mathrm{MoO}_{2} \mathrm{~L}\right]$, derived from the tridentate aroylhydrazone 2-amino- $N$ '-(2-hydroxy-3-methylbenzylidene)benzohydrazide $\left(\mathrm{H}_{2} \mathrm{~L}\right.$; Scheme 1), was studied.

\section{Experimental}

\section{1. Materials and Methods}

All chemicals and solvents used were of analytical reagent grade and used as received. $\mathrm{MoO}_{2}(\mathrm{acac})_{2}$ was prepared as described in the literature. ${ }^{7}$ Micro analyses for $\mathrm{C}, \mathrm{H}$, $\mathrm{N}$ were carried out using a Perkin Elmer $2400 \mathrm{CHNS} / \mathrm{O}$ elemental analyzer. FT-IR spectra were recorded on a FT-IR 8400-Shimadzu as $\mathrm{KBr}$ discs in the range of 400-4000 $\mathrm{cm}^{-1}$. ${ }^{1} \mathrm{H}$ NMR spectra were recorded at $25^{\circ} \mathrm{C}$ on the Bruker AVANCE $300 \mathrm{MHz}$ spectrometer. X-ray diffraction data were collected using a Bruker Smart Apex II diffractometer.

\section{2. Synthesis of $H_{2} L$}

A methanolic solution $(10 \mathrm{~mL})$ containing 1.00 mmol of 2-hydroxy-3-methylbenzaldehyde $(0.136 \mathrm{~g})$ was 
added dropwise to a methanolic solution of 2-aminobenzohydrazide $(1.00 \mathrm{mmol}, 0.151 \mathrm{~g})$ with constant stirring. The mixture was refluxed for $30 \mathrm{~min}$, and the resulting precipitate was filtered off, washed with cold methanol and dried in desiccator over silica gel. Yield: $0.23 \mathrm{~g}, 85 \%$. For $\mathrm{C}_{15} \mathrm{H}_{15} \mathrm{~N}_{3} \mathrm{O}_{2}$ : anal. calcd., \%: $\mathrm{C}, 66.90 ; \mathrm{H}, 5.61$; N, 15.60. Found, \%: C, 66.73; H, 5.72; N, 15.75. FT-IR $(\mathrm{KBr}), \mathrm{cm}^{-1}: \quad v(\mathrm{NH})$ 3232, $\quad v(\mathrm{OH}) 3431, \quad v\left(\mathrm{CH}_{\mathrm{ar}}\right)$ 2830-3085, v $(\mathrm{C}=\mathrm{O}) 1650, v(\mathrm{C}=\mathrm{N}) 1615, v(\mathrm{~N}-\mathrm{N}) 1149$, $v(\mathrm{C}-\mathrm{O})$ 1287. ${ }^{1} \mathrm{H}$ NMR (300 MHz, DMSO- $d^{6}$, ppm): $\delta=$ 12.10 (s, 1H; NH), 11.05 (s, 2H, NH $\left.H_{2}\right), 10.76(\mathrm{~s}, 1 \mathrm{H} ; \mathrm{OH})$, $8.70(\mathrm{~s}, 1 \mathrm{H} ; \mathrm{CH}=\mathrm{N}), 6.80-7.15(\mathrm{~m}, 5 \mathrm{H}, \mathrm{ArH}), 7.43(\mathrm{~d}, 1 \mathrm{H}$, $\operatorname{ArH}), 7.69$ (d, 1H, $\operatorname{ArH}), 2.13$ (s, 3H, $\mathrm{CH}_{3}$ ).

\section{3. Synthesis of $\left[\mathrm{MoO}_{2} \mathrm{~L}\right]$}

A methanolic solution $(10 \mathrm{~mL})$ of $\mathrm{MoO}_{2}(\mathrm{acac})_{2}$ $(0.10 \mathrm{mmol}, 0.033 \mathrm{~g})$ was added to a solution of $\mathrm{H}_{2} \mathrm{~L}(0.10$ mmol, $0.027 \mathrm{~g})$ in methanol $(10 \mathrm{~mL})$ and the resulting orange mixture was refluxed for $30 \mathrm{~min}$. After cooling, the solution was filtered and left to stand overnight. Orange single crystals suitable for crystallography separated after a week and were dried in a vacuum desiccator over silica gel. Yield: $0.021 \mathrm{~g}, 63 \%$. For $\mathrm{C}_{15} \mathrm{H}_{13} \mathrm{MoN}_{3} \mathrm{O}_{4}$ : anal. calcd., $\%$ : C, 45.58; H, 3.32; N, 10.63. Found, \%: C, 45.40; H, $3.41 ; \mathrm{N}, 10.54$. IR $(\mathrm{KBr}) \mathrm{cm}^{-1}: \mathrm{v}(\mathrm{OH}) 3466, v\left(\mathrm{NH}_{2}\right) 3340$, $v(\mathrm{NH}) 3233, v(\mathrm{CH}) 2810-2990, v(\mathrm{C}=\mathrm{N}) 1611, v\left(\mathrm{C}=\mathrm{C}_{\text {ring }}\right)$ 1434, v(N-N) 1157, v(C-O) 1257, v sym $\left(\right.$ cis $\left.-\mathrm{MoO}_{2}\right) 949$, $v_{\text {asym }}\left(\right.$ cis $\left.-\mathrm{MoO}_{2}\right)$ 861. ${ }^{1} \mathrm{H}$ NMR $\left(400 \mathrm{MHz}, \mathrm{DMSO}-d^{6}\right.$, ppm): $\delta=11.13\left(\mathrm{~s}, 2 \mathrm{H}, \mathrm{NH}_{2}\right), 8.77(\mathrm{~s}, 1 \mathrm{H} ; \mathrm{CH}=\mathrm{N})$, 6.70-7.80 (m, 7H; $\mathrm{ArH}), 2.15\left(\mathrm{~s}, 3 \mathrm{H}, \mathrm{CH}_{3}\right)$.

\section{4. X-Ray Structure Determination}

The crystal of the complex was measured on a Bruker SMART Apex II CCD diffractometer using Mo K $\alpha$ ra- diation $(\lambda=0.71073 \AA)$ and a graphite monochromator at $25^{\circ} \mathrm{C}$. Unit cell and reflection data were obtained by standard methods ${ }^{8}$ and are summarized in Table 1. The structure was solved, refined, and prepared for publication using the SHEXTL package (structure solution refinements and molecular graphics). ${ }^{9}$ The structure was solved using direct methods and refined on $F^{2}$ using full matrix least squares techniques with anisotropic displacement factors for all non-hydrogen atoms. The amino and methanol

Table 1. Crystal data and structure refinement for the complex

\begin{tabular}{ll}
\hline Parameter & Value \\
\hline Molecular formula & $\mathrm{C}_{15} \mathrm{H}_{13} \mathrm{MoN}_{3} \mathrm{O}_{4}$ \\
Formula weight & 395.22 \\
Temperature $(\mathrm{K})$ & $298(2)$ \\
Crystal system & triclinic \\
Space group & $P \overline{1}$ \\
$a(\AA)$ & $9.7363(14)$ \\
$b(\AA)$ & $11.7491(17)$ \\
$c(\AA)$ & $13.908(2)$ \\
$\alpha\left(^{\circ}\right)$ & $102.355(2)$ \\
$\beta\left(^{\circ}\right)$ & $94.650(2)$ \\
$\gamma\left({ }^{\circ}\right)$ & $104.522(2)$ \\
$V\left(\AA^{3}\right)$ & $1489.1(4)$ \\
$Z$ & 4 \\
$D_{\text {calc }}\left(\mathrm{g} /\right.$ cm $\left.^{3}\right)$ & 1.763 \\
Absorption coefficient $\left(\mathrm{mm}^{-1}\right)$ & 0.905 \\
$F(000)$ & 792 \\
Reflections collected & 12376 \\
Independent reflection $\left(R_{\text {int }}\right)$ & $5427(0.0357)$ \\
Reflections observed $(I>2 \sigma(I))$ & 4342 \\
Data/restraints/parameters & $5427 / 6 / 429$ \\
Goodness-of-fit on $F^{2}$ & 1.091 \\
Final $R$ indices $(I>2 \sigma(I))$ & $0.0469,0.1137$ \\
$R$ indices (all data) & $0.0612,0.1232$ \\
Highest peak and deepest hole $\left(\mathrm{e} \AA^{-3}\right)$ & $1.072,-0.969$ \\
\hline
\end{tabular}

Table 2. Selected bond lengths $(\AA)$ and angles $\left(^{\circ}\right)$ for the complex

\begin{tabular}{lrlr}
\hline Bond lengths (̊) & & & \\
\hline $\mathrm{Mo}(1)-\mathrm{O}(1)$ & $1.912(3)$ & $\mathrm{Mo}(1)-\mathrm{O}(2)$ & $1.992(3)$ \\
$\mathrm{Mo}(1)-\mathrm{O}(3)$ & $1.693(4)$ & $\mathrm{Mo}(1)-\mathrm{O}(4)$ & $1.706(4)$ \\
$\mathrm{Mo}(1)-\mathrm{N}(1)$ & $2.231(4)$ & $\mathrm{Mo}(2)-\mathrm{O}(5)$ & $1.905(3)$ \\
$\mathrm{Mo}(2)-\mathrm{O}(6)$ & $1.993(3)$ & $\mathrm{Mo}(2)-\mathrm{O}(7)$ & $1.691(4)$ \\
$\mathrm{Mo}(2)-\mathrm{N}(4)$ & $2.242(4)$ & $\mathrm{Mo}(2)-\mathrm{O}(8)$ & $1.700(3)$ \\
\hline Bond angles $\left(^{\circ}\right)$ & & & $99.78(18)$ \\
$\mathrm{O}(3)-\mathrm{Mo}(1)-\mathrm{O}(4)$ & $106.7(2)$ & $\mathrm{O}(3)-\mathrm{Mo}(1)-\mathrm{O}(1)$ & $97.34(17)$ \\
$\mathrm{O}(4)-\mathrm{Mo}(1)-\mathrm{O}(1)$ & $101.66(17)$ & $\mathrm{O}(3)-\mathrm{Mo}(1)-\mathrm{O}(2)$ & $150.13(15)$ \\
$\mathrm{O}(4)-\mathrm{Mo}(1)-\mathrm{O}(2)$ & $96.57(16)$ & $\mathrm{O}(1)-\mathrm{Mo}(1)-\mathrm{O}(2)$ & $153.65(17)$ \\
$\mathrm{O}(3)-\mathrm{Mo}(1)-\mathrm{N}(1)$ & $98.35(18)$ & $\mathrm{O}(4)-\mathrm{Mo}(1)-\mathrm{N}(1)$ & $100.15(17)$ \\
$\mathrm{O}(1)-\mathrm{Mo}(1)-\mathrm{N}(1)$ & $81.61(15)$ & $\mathrm{O}(2)-\mathrm{Mo}(1)-\mathrm{N}(1)$ & $96.83(16)$ \\
$\mathrm{O}(7)-\mathrm{Mo}(2)-\mathrm{O}(8)$ & $106.79(18)$ & $\mathrm{O}(7)-\mathrm{Mo}(2)-\mathrm{O}(5)$ & $149.17(14)$ \\
$\mathrm{O}(8)-\mathrm{Mo}(2)-\mathrm{O}(5)$ & $101.52(16)$ & $\mathrm{O}(7)-\mathrm{Mo}(2)-\mathrm{O}(6)$ & $155.41(16)$ \\
$\mathrm{O}(8)-\mathrm{Mo}(2)-\mathrm{O}(6)$ & $97.92(16)$ & $\mathrm{O}(5)-\mathrm{Mo}(2)-\mathrm{O}(6)$ & $71.37(13)$ \\
$\mathrm{O}(7)-\mathrm{Mo}(2)-\mathrm{N}(4)$ & $96.62(16)$ & $\mathrm{O}(8)-\mathrm{Mo}(2)-\mathrm{N}(4)$ & \\
$\mathrm{O}(5)-\mathrm{Mo}(2)-\mathrm{N}(4)$ & $81.21(14)$ & $\mathrm{O}(6)-\mathrm{Mo}(2)-\mathrm{N}(4)$ &
\end{tabular}


$\mathrm{H}$ atoms were located from a difference Fourier map and refined isotropically, with $\mathrm{N}-\mathrm{H}, \mathrm{O}-\mathrm{H}$, and $\mathrm{H} \cdots \mathrm{H}$ distances restrained to $0.90(1), 0.85(1)$, and 1.43(2) $\AA$, respectively. Positions of the remaining hydrogen atoms were calculated from the geometry of the molecular skeleton and their thermal displacement parameters were refined isotropically on a groupwise basis. Selected bond lengths and angles are reported in Table 2. H-bonding distances and angles are shown in Table 3.

Table 3. Hydrogen bonding interactions $\left(\AA,^{\circ}\right)$

\begin{tabular}{lcccc}
\hline $\boldsymbol{D}-\mathbf{H} \cdots \boldsymbol{A}$ & $\boldsymbol{d}(\boldsymbol{D}-\mathbf{H})$ & $\boldsymbol{d}(\mathbf{H} \cdots \boldsymbol{A})$ & $\boldsymbol{d}(\boldsymbol{D} \cdots \boldsymbol{A})$ & $\begin{array}{c}\text { Angle } \\
(\boldsymbol{D}-\mathbf{H} \cdots \boldsymbol{A})\end{array}$ \\
\hline $\mathrm{N}(3)-\mathrm{H}(3 \mathrm{~A}) \cdots \mathrm{N}(2)$ & $0.90(1)$ & $2.12(4)$ & $2.795(5)$ & $131(5)$ \\
$\mathrm{N}(6)-\mathrm{H}(6 \mathrm{~B}) \cdots \mathrm{O}(4)^{\mathrm{i}}$ & $0.90(1)$ & $2.50(3)$ & $3.311(5)$ & $151(5)$ \\
$\mathrm{N}(6)-\mathrm{H}(6 \mathrm{~A}) \cdots \mathrm{N}(5)$ & $0.90(1)$ & $2.13(4)$ & $2.810(5)$ & $132(5)$ \\
$\mathrm{N}(3)-\mathrm{H}(3 \mathrm{~B}) \cdots \mathrm{O}(8)$ & $0.90(1)$ & $2.51(3)$ & $3.308(5)$ & $149(5)$ \\
\hline
\end{tabular}

Symmetry code: i) $x, 1+y,-1+z$.

\section{5. Catalytic Epoxidation of Olefins}

To a solution of olefins $(0.28 \mathrm{mmol}), \mathrm{NaHCO}_{3}(0.11$ $\mathrm{mmol})$ and catalyst $\left(9.4 \times 10^{-4} \mathrm{mmol}\right)$ in $\mathrm{MeCN}(0.5 \mathrm{~mL})$ was added $\mathrm{H}_{2} \mathrm{O}_{2}\left(1.1 \mathrm{mmol}, 30 \% \mathrm{H}_{2} \mathrm{O}_{2}\right.$ in water) as oxidant. After the reaction was over, for the products analysis, the solution was subjected to multiple ether extraction, and the extract was also concentrated down to $0.5 \mathrm{~m}$ $\mathrm{L}$ by distillation in a rotary evaporator at room temperature and then a sample $(2 \mu \mathrm{L})$ was taken from the solution and analyzed by GC. The retention times of the peaks were compared with those of commercial standards, and chlorobenzene was used as an internal standard for GC yield calculation.

\section{Results and Discussion}

\section{1. Synthesis and Characterization}

The reaction of $\mathrm{MoO}_{2}(\mathrm{acac})_{2}$ with the tridentate aroylhydrazine ligand $\mathrm{H}_{2} \mathrm{~L}$ in methanol led to the formation of cis- $\mathrm{MoO}_{2}$ complex in a good yield (Scheme 2). The complex is stable at room temperature and soluble in DMSO, DMF, ethanol, acetonitrile and less soluble in ot-

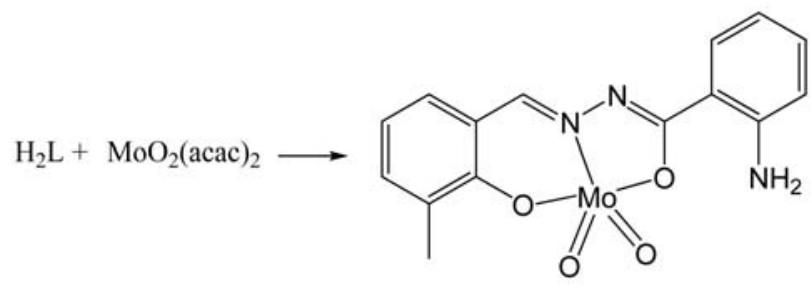

Scheme 2. Synthesis procedure of the complex her common solvents like dichloromethane, chloroform, and insoluble in benzene, $n$-hexane and $\mathrm{CCl}_{4}$.

\section{2. ${ }^{1} \mathrm{H}$ NMR Spectra}

${ }^{1} \mathrm{H}$ NMR data of the aroylhydrazone ligand when compared with the complex reveals that the ligand serves as tridentate binegative ONO donor with amino group remaining free. The amino residue of the ligand shows signal for $\mathrm{N}-\mathrm{H}$ at $11.05 \mathrm{ppm}$, which is found unperturbed in the complex. The disappearance of the signal at 12.10 $\mathrm{ppm}$ in the free ligand upon complexation suggests that during complexation the [-CO-NH-] group undergoes tautomerization to $[-\mathrm{C}(\mathrm{OH})=\mathrm{N}-]$ followed by deprotonation of the $-\mathrm{OH}$ group. The azomethine $\mathrm{C}-\mathrm{H}$ signal in the complex is shifted up-field from its original position in the free ligand upon coordination of the $-\mathrm{CH}=\mathrm{N}-$ group, on account of reduction of electron density at the azomethine $\mathrm{C}-\mathrm{H}$. The aromatic protons also show some deviation in the complex as compared to the free ligand since in the complex they are in direct conjugation to the coordinated $\mathrm{O}$ and $\mathrm{N}$ of the hydrazone ligands.

\section{3. IR Spectra}

IR spectrum of the free aroylhydrazone ligand shows multiple bands at $3232 \mathrm{~cm}^{-1}$ for $\mathrm{v}(\mathrm{N}-\mathrm{H})$ of amino group, $1650 \mathrm{~cm}^{-1}$ for $v(\mathrm{C}=\mathrm{O})$ and $3431 \mathrm{~cm}^{-1}$ for $v(\mathrm{O}-\mathrm{H}) .{ }^{10}$ The $v(\mathrm{C}=\mathrm{O})$ band is absent in the spectrum of the complex as the ligand binds in binegative mode losing protons from the carbohydrazide group. The strong peak at $1611 \mathrm{~cm}^{-1}$ can be assigned to $v(\mathrm{C}=\mathrm{N}) .{ }^{11}$ The complex exhibits two characteristic bands at $949 \mathrm{~cm}^{-1}$ and 861 $\mathrm{cm}^{-1}$ for symmetric and antisymmetric stretching of cis $\mathrm{MoO}_{2}$ core. $^{12}$

\section{4. Structure Description}

The perspective view of the complex together with the atom numbering scheme are shown in Fig. 1. The asymmetric unit of the complex contains two complex molecules which are linked by hydrogen bonds. The coordination geometry around each molybdenum atom in the complex reveals a distorted square pyramidal environment with an $\mathrm{NO}_{4}$ chromophore. The ligand molecule behaves as binegative tridentate one binding through the phenolate oxygen, the enolate oxygen and the imine nitrogen and occupies three positions in the basal plane. The fourth donor of the basal plane is furnished by one oxo group. The other oxo group is located at the apical position. The Mo atoms are found to be deviated from the corresponding mean basal planes by $0.365(1) \AA$ for $\operatorname{Mo}(1)$ molecule and $0.354(1) \AA$ for $\mathrm{Mo}(2)$ molecule. The $\mathrm{C}(8)-\mathrm{O}(2)$ and $\mathrm{C}(23)-\mathrm{O}(6)$ bond lengths are closer to single bond length rather than $\mathrm{C}-\mathrm{O}$ double bond length. However, the shorter length compared to $\mathrm{C}-\mathrm{O}$ single bond 
may be attributed to extended electron delocalization in the ligand. Similarly shortening of $\mathrm{C}(8)-\mathrm{N}(2)$ and $\mathrm{C}(23)-\mathrm{N}(5)$ lengths together with the elongation of $\mathrm{N}(1)-\mathrm{N}(2)$ and $\mathrm{N}(4)-\mathrm{N}(5)$ lengths also supports the electron cloud delocalization in the ligand system. The ligand molecules form five-membered and six-membered chelate rings with the Mo centers.

The question arises as to whether the coordination polyhedra around the five-coordinated Mo atoms can be described as distorted square pyramid or distorted trigonal bipyramid. Further information can be obtained by determining the structural index $\tau$ which represents the relative amount of trigonality (square pyramid, $\tau=0$; trigonal bipyramid, $\tau=1) ; \tau=(\beta-\alpha) / 60^{\circ}, \alpha$ and $\beta$ being the two largest angles around the central atom. ${ }^{13}$ The values of $\tau$ are 0.059 for $\mathrm{Mo}(1)$ and 0.104 for $\mathrm{Mo}(2)$. The coordination geometries of the Mo atoms in the complex can therefore be described as distorted square pyramids. Molecules are linked through intermolecular hydrogen bonds to form 2D sheets (Fig. 2).

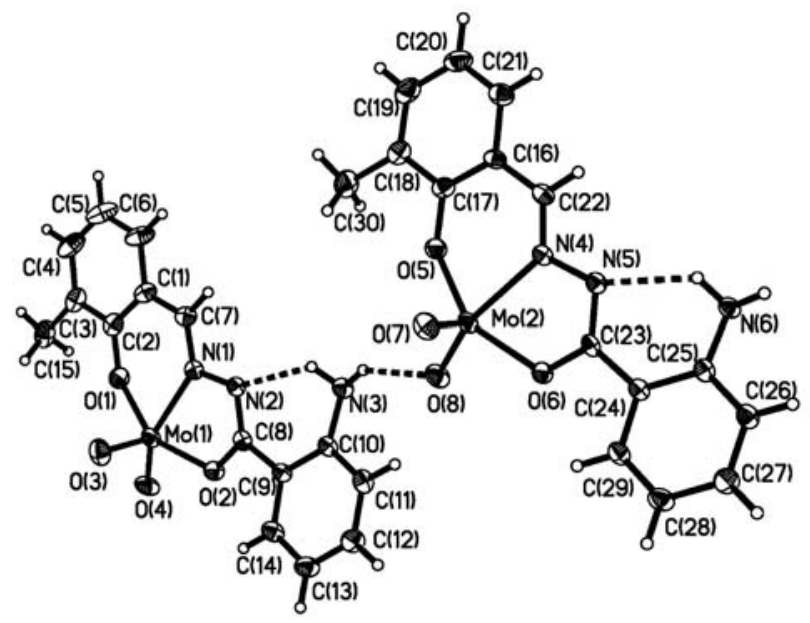

Figure 1. An ORTEP diagram of the complex with atom labeling scheme and $30 \%$ probability thermal ellipsoids for all non-hydrogen atoms. Hydrogen bonds are shown as dashed lines.

\section{5. Catalytic Property}

The complex showed effective catalytic property in the oxidation of various olefins to their corresponding epoxides. The details of catalytic properties with respect to epoxidation of olefins with the complex as catalyst are given in Table 4. Excellent epoxide yields and selectivity were observed for all aliphatic and aromatic substrates. The results of catalytic studies using dioxomolybdenum catalysts reveal that the efficiency of catalyst toward all the substrates is similar with maximum conversion, TON, and selectivity. The mechanism for the epoxidation of various olefins to epoxides using the two complexes as catalysts has been proposed by comparison with the literature report (Scheme 3). ${ }^{14}$ When $\mathrm{H}_{2} \mathrm{O}_{2}$ was used as a sole oxidant the catalytic efficiency is not high, but when $\mathrm{NaHCO}_{3}$ was added as a co-catalyst the efficiency of the system increases many times. The key aspect of such a reaction is that $\mathrm{H}_{2} \mathrm{O}_{2}$ and hydrogen carbonate react in an equilibrium process to

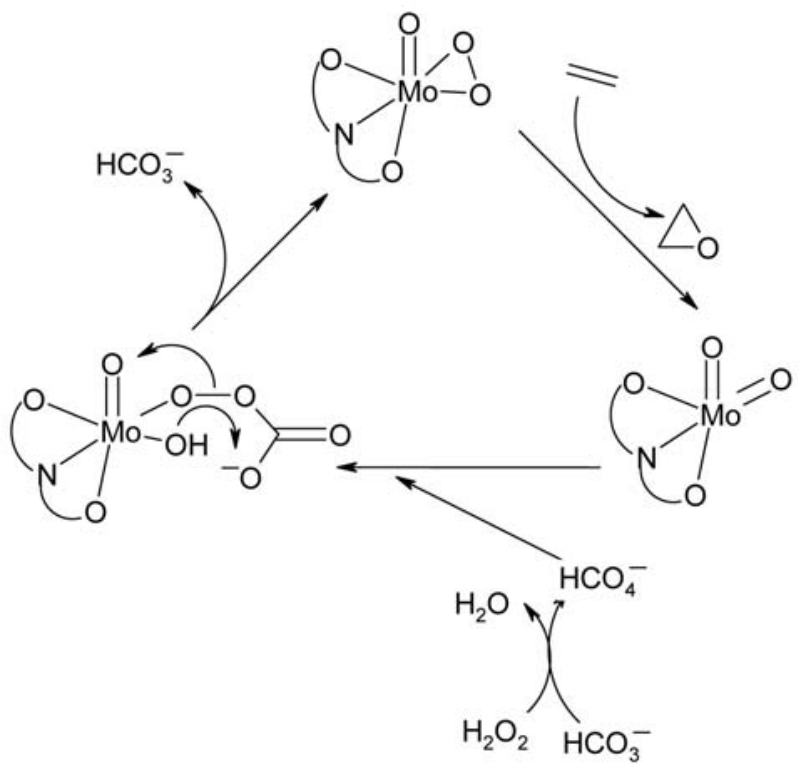

Scheme 3. Proposed mechanism of catalytic oxidation process

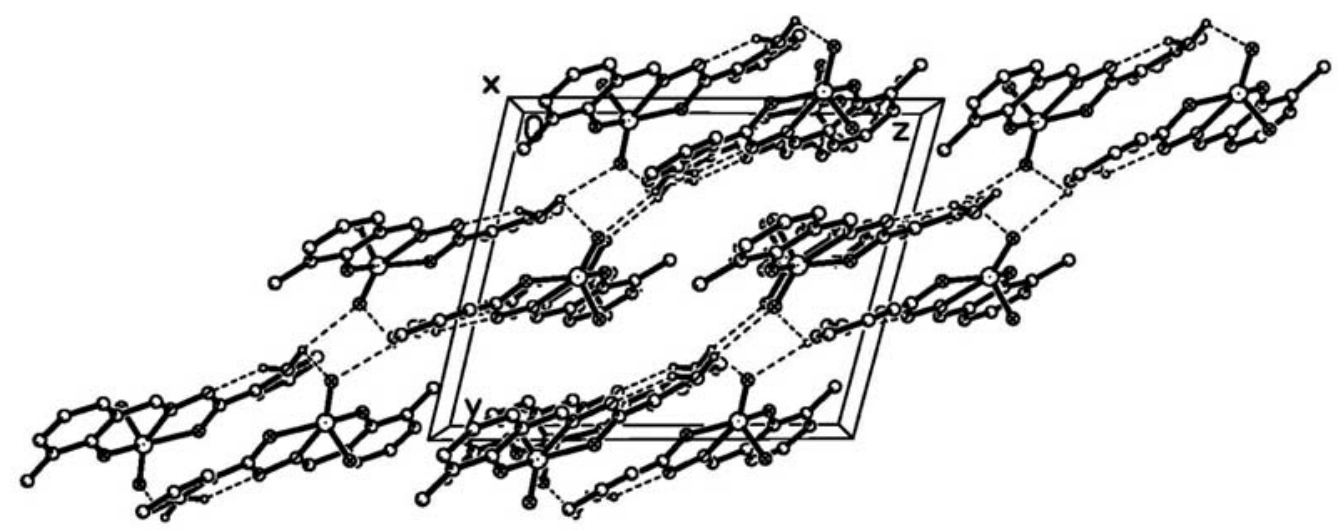

Figure 2. Packing diagram of the complex, viewed along the $x$ axis. Hydrogen bonds are shown as dashed lines. 
Table 4. The catalytic oxidation results ${ }^{\mathrm{a}}$

\begin{tabular}{|c|c|c|c|}
\hline Substrate & Product & Conversion $(\%)^{b}(\mathrm{TON})^{\mathrm{c}}$ & Selectivity $(\%)^{\mathrm{d}}$ \\
\hline & & $100(321)$ & 100 \\
\hline & & $100(305)$ & 100 \\
\hline & & $91(287)$ & 100 \\
\hline & & $93(292)$ & 100 \\
\hline
\end{tabular}

${ }^{a}$ The molar ratios for catalyst: substrate: $\mathrm{NaHCO}_{3}: \mathrm{H}_{2} \mathrm{O}_{2}$ are 1:298:117:1170. The reactions were performed in (70:30) $\mathrm{mixture}$ of $\mathrm{CH}_{3} \mathrm{OH} / \mathrm{CH}_{2} \mathrm{Cl}_{2}$ $(1.2 \mathrm{~mL})$ under air at room temperature. ${ }^{\mathrm{b}} \mathrm{The} \mathrm{GC}$ conversion $(\%)$ are measured relative to the starting olefin after $74.5 \mathrm{~min} .{ }^{\mathrm{c}} \mathrm{TON}=(\mathrm{mmol}$ of product $) / \mathrm{mmol}$ of catalyst. ${ }^{\mathrm{d}}$ Selectivity to epoxide $=($ epoxide $\% /($ epoxide $\%+$ aldehyde $\%)) \times 100$.

produce peroxymonocarbonate, $\mathrm{HCO}_{4}$, which is a more reactive nucleophile than $\mathrm{H}_{2} \mathrm{O}_{2}$ and speeds up the epoxidation reaction. ${ }^{15}$ The basic principle of the catalytic reaction is the conversion of oxoperoxo-complex to dioxo-complex transferring oxo species to the olefins and the conversion of dioxo complex to the oxoperoxo complex reacting with $\mathrm{HCO}_{4}^{-}$to regain the catalytic activity.

\section{Conclusion}

A novel dioxidomolydenum(VI) complex with aroylhydrazone ligand 2-amino- $N$ '-(2-hydroxy-3-methylbenzylidene)benzohydrazide has been prepared and structurally characterized using X-ray structure analysis, FT-IR and ${ }^{1} \mathrm{H}$ NMR spectra. The complex has square pyramidal geometry with positions around the central atom being occupied with donor atoms of the aroylhydrazone ligand, and two oxo groups. The complex showed effective catalytic property in the oxidation of various olefins to their corresponding epoxides.

\section{Supplementary Material}

CCDC reference number 1435811 contains the supplementary crystallographic data for this article. These data can be obtained free of charge at http://www. ccdc.cam. ac.uk, or from Cambridge Crystallographic Data Center, 12 Union Road, Cambridge CB2 1EZ, UK; Fax: +44 1223 336 033; Email: deposit@ ccdc.cam.ac.uk.

\section{References}

1. (a) A. Galani, V. Tsitsias, D. Stellas, V. Psycharis, C. P. Rap- topoulou, A. Karaliota, J. Inorg. Biochem. 2015, 142, 109-117; http://dx.doi.org/10.1016/j.jinorgbio.2014.10.004

(b) M.-E. Jean, K. Phalyvong, J. Forest-Drolet, J. P. Bellenger, Soil Biol. Biochem. 2013, 67, 140-146; http://dx.doi.org/10.1016/j.soilbio.2013.08.018

(c) G. J. Gilleaudeau, L. C. Kah, Chem. Geol. 2013, 356, 21-37. http://dx.doi.org/10.1016/j.chemgeo.2013.07.004

2. (a) K. Arashiba, E. Kinoshita, S. Kuriyama, A. Eizawa, K. Nakajima, H. Tanaka, K. Yoshizawa, Y. Nishibayashi, J. Am. Chem. Soc. 2015, 137, 5666-5669;

http://dx.doi.org/10.1021/jacs.5b02579

(b) E. Kinoshita, K. Arashiba, S. Kuriyama, A. Eizawa, K. Nakajima, Y. Nishibayashi, Eur. J. Inorg. Chem. 2015, 1789-1794; http://dx.doi.org/10.1002/ejic.201500017

(c) S. Budhi, C. Mukarakate, K. Lisa, S. Pylypenko, P. N. Ciesielski, M. M. Yung, B. S. Donohoe, R. Katahira, M. R. Nimlos, B. G. Trewyn, Green Chem. 2015, 3035-3046. http://dx.doi.org/10.1039/C4GC02477J

3. (a) M. Pramanik, A. Bhaumik, ChemCatChem 2014, 6, 2577-2586; http://dx.doi.org/10.1002/cctc.201402291

(b) Z. Moradi-Shoeili, M. Zare, M. Bagherzadeh, M. Kubicki, D. M. Boghaei, J. Coord. Chem. 2015, 68, 548-559; http://dx.doi.org/10.1080/00958972.2014.993321

(c) T. Baskaran, R. Kumaravel, J. Christopher, T. G. Ajithkumar, A. Sakthivel, New J. Chem. 2015, 39, 3758-3764. http://dx.doi.org/10.1039/C4NJ02402H

4. (a) S.-S. Qian, X. Zhao, J. Wang, Z. You, Acta Chim. Slov. 2015, 62, 828-833;

(b) K.-H. Yang, Acta Chim. Slov. 2014, 61, 629-636.

5. (a) S. Y. Ebrahimipour, H. Khabazadeh, J. Castro, I. Sheikhshoaie, A. Crochet, K. M. Fromm, Inorg. Chim. Acta 2015, 427, 52-61; http://dx.doi.org/10.1016/j.ica.2014.11.023

(b) N. K. Ngan, K. M. Lo, C. S. R. Wong, Polyhedron 2012, 33, 235-251; http://dx.doi.org/10.1016/j.poly.2011.11.057

(c) S.-P. Gao, J. Coord. Chem. 2011, 64, 2869-2877; http://dx.doi.org/10.1080/00958972.2011.608163 
(d) N. K. Ngan, K. M. Lo, C. S. R. Wong, Polyhedron 2011, 30, 2922-2932;

http://dx.doi.org/10.1016/j.poly.2011.08.038

(e) R. Dinda, P. Sengupta, S. Ghosh, H. Mayer-Figge, W. S. Sheldrick, J. Chem. Soc. Dalton Trans. 2002, 4434-4439; http://dx.doi.org/10.1039/b207129k

(f) S. Gupta, A. K. Barik, S. Pal, A. Hazra, S. Roy, R. J. Butcher, S. K. Kar, Polyhedron 2007, 26, 133-141;

http://dx.doi.org/10.1016/j.poly.2006.08.001

(g) R. Dinda, S. Ghosh, L. R. Falvello, M. Tomas, T. C. W. Mak, Polyhedron 2006, 25, 2375-2382;

http://dx.doi.org/10.1016/j.poly.2006.02.002

(h) M. Mancka, W. Plass, Inorg. Chem. Commun. 2007, 10, 677-680; http://dx.doi.org/10.1016/j.inoche.2007.02.029

(i) R. Debel, A. Buchholz, W. Plass, Z. Anorg. Allg. Chem. 2008, 634, 2291-2298;

http://dx.doi.org/10.1002/zaac.200800231

(j) S. Gupta, B. K. Barik, T. N. Mandal, S. Roy, N. Guchhait, R. J. Butcher, S. K. Kar, Polyhedron 2009, 28, 3577-3585. http://dx.doi.org/10.1016/j.poly.2009.07.053

6. R. Dinda, P. Sengupta, S. Ghosh, W. S. Sheldrick, Eur. J. Inorg. Chem. 2003, 363-369.

http://dx.doi.org/10.1002/ejic.200390049

7. G. J. J. Chen, J. W. McDonald, W. E. Newton, Inorg. Chem. 1976, 15, 2612-2615. http://dx.doi.org/10.1021/ic50165a008

8. (a) Bruker, SMART (Version 5. 624) and SAINT (Version 6.

04) Programs Using the Windows NT System, Bruker AXS
Inc., Madison, WI, USA, 2001;

(b) G. M. Sheldrick, Acta Crystallogr. 2008, A64, 112-122. http://dx.doi.org/10.1107/S0108767307043930

9. G. M. Sheldrick, SHELXTL, Version 5.10, Bruker AXS Inc., Madison, WI, USA, 1997.

10. I. Sheikhshoaie, S. Y. Ebrahimipour, M. Sheikhshoaie, H. A. Rudbari, M. Khaleghi, G. Bruno, Spectrochim. Acta A 2014, 124, 548-555. http://dx.doi.org/10.1016/j.saa.2014.01.043

11. S. Y. Ebrahimipour, J. T. Mague, A. Akbari, R. Takjoo, J. Mol. Struct. 2012, 1028, 148-155.

http://dx.doi.org/10.1016/j.molstruc.2012.05.076

12. (a) R. Takjoo, A. Akbari, M. Ahmadi, H. A. Rudbari, G. Bruno, Polyhedron 2013, 55, 225-232;

http://dx.doi.org/10.1016/j.poly.2013.02.078

(b) S. Alghool, C. Slebodnick, Polyhedron 2014, 67, 11-18; http://dx.doi.org/10.1016/j.poly.2013.08.059

(c) S. Pasayat, S. P. Dash, S. Roy, R. Dinda, S. Dhaka, M. R. Maurya, W. Kaminsky, Y. P. Patil, M. Nethaji, Polyhedron 2014, 67, 1-10. http://dx.doi.org/10.1016/j.poly.2013.08.055

13. A. W. Addison, T. N. Rao, J. Reedijk, J. van Rijn, G. C. Verschoor, J. Chem. Soc. Dalton Trans. 1984, 1349-1356. http://dx.doi.org/10.1039/dt9840001349

14. S. K. Maiti, S. Dinda, S. Banerjee, A. K. Mukherjee, R. Bhattacharyya, Eur. J. Inorg. Chem. 2008, 2038-2051. http://dx.doi.org/10.1002/ejic.200701043

15. M. Zakeri, M. Moghadam, I. Mohammadpoor-Baltork, S. Tangestaninejad, V. Mirkhani, A. R. Khosropour, J. Coord. Chem. 2012, 65, 1144-1157.

\section{Povzetek}

Sintetizirali smo nov dioksidomolibdenov kompleks, $\left[\mathrm{MoO}_{2} \mathrm{~L}\right]$, z vezavo troveznega aroilhidrazona 2-amino- $N^{\prime}$-(2-hidroksi-3-methilbenziliden)benzohidrazida $\left(\mathrm{H}_{2} \mathrm{~L}\right)$ in ga okarakterizirali $\mathrm{z}$ elementno analizo, FT-IR, ${ }^{1} \mathrm{H}$ NMR in monokristalno rentgensko difrakcijo. Kompleks ima popačeno kvadratno piramidalno strukturo, kjer je aroilhidrazonski ligand dinegativni donor, medtem ko amino-N skupina ni koordinirana na kovinski center. Monokristalna strukturna analiza razkrije, da je Mo(VI) center koordiniran z donorskimi atomi dinegativnega aroilhidrazonskega liganda in dveh oksido skupin. Kristalna struktura je stabilizirana z vodikovimi vezmi. Kompleks je učinkovit katalizator za epoksidacijo olefinov z vodikovim peroksidom kot oksidantom in z natrijevim hidrogenkarbonatom kot kokatalizatorjem. 